\title{
Satisfaction of evaluator relevant factors of work of the class teacher
}

\author{
Nazyktere HASANI \\ PhD candidate of Europian University of Tirana \\ nhasani14@hotmail.com)
}

DOI:10.5901/mjss.2014.v5n19p343

\begin{abstract}
The class teacher is one of the main agents, who with his very substantial role, as a guide and accompanying and advisor, make the students feel as an equal subject in school. The class teacher with his personality and difficult pedagogical role that has been in the spotlight, significantly reflects to students, parents and subject teachers in creating an education, development, and overall genuine progress through the commitment and organizational work and through his pedagogical leadership with the class, creating such conditions that students are satisfied with the school. The class teacher with his pedagogical role brings a better access to students in their school life, making systematic tracking of student work for greater academic achievement, being the supportive guidance and assistance, cooperative and mediator of the solutions of problems that arise in the classroom, especially with the subject teachers. This paper elaborated the organizational, communicational and collaborative work of the class teacher, focusing on evaluator attitudes of relevant factors and determinants of the class teachers' work.
\end{abstract}

Key words: work of the class teacher, satisfaction, students, parent, teachers

\section{Introduction}

In this study the evaluation of the class teachers' work from the perspective and opinions of students, parents and subject teachers are treated, considering that these agents of the school are the best estimators of the class teachers' work. The class teacher with his pedagogical role brings a better students access in their school life, making systematic tracking of students' work for greater academic achievement, being the supportive guidance and assistance, cooperative and mediator of the problems solution that exist in the classroom, especially with subject teachers. With his dedication to his job, with the flexibility and collaborative manner with students, parents and subject teachers, he creates a positive overall climate and affects the image of the school. There are many important elements that define and make the class teachers' work special, and one of them is tolerance, respect, establishment of a mutual trust, flexibility, willingness and being ready for a dialogue with all important people of the school. In order the work with students to function well, it is necessary the cooperation with parents. Proper communication of the class and family, creation of spaces for parents to be an active part of school life of their children, are extremely important aspects of the function of the work with students because studentschildren feel themselves safe, create in themselves a trust, so putting the forces together, problems that would be created in the school would easier be solved. The class teacher should design objectives which with organization, support, respect, communication, encouragement of tolerance, creating a sense of trust between pupils, students and subject teachers and parents, cooperating together, reaches the goal and thus succeeds to realize its objectives designed before. In order to work the class leadership and management, he should be professionally prepared, to have ideas on how to organize better his work with the whole class, to find effective ways and forms, which would create a democratic spirit in the classroom. This study is of a particular importance because to us there were no such studies and to the work of the class teacher no importance is shown. If we see from the educational practices, we notice that the class teachers are least aware of their function as a leader and director of the classroom, lack of education, expert training, adequate training programs for the class teachers and manuals for their work. This study perhaps would arouse curiosity and encourage a greater interest that in the future to focus more on the education and training of teachers for a professional pedagogical preparation, for an organizational work and leadership of the class, to be an initiative stone of the gaps filling and to provide basic recommendations.

The object of this study was to obtain evaluative attitudes and opinions of students, parents and subject teachers toward the work of the class teacher. The aim of the study was to highlight the evaluative attitudes of students, parents and subject teachers' perceptions to the class teacher work, and to present some of their opinions in order to contribute to a better 
approach of the class teachers' work. Research question of the study was: How do you students, parents, students and subject teachers evaluate the organizational, cooperative and supportive role of the class teacher? Do we have differences in the perceptions of students, parents and subject teachers?

\section{Objectives of the research:}

Identification and reflection of evaluative attitudes toward the work of the class teacher.

Analysis, comparison and interpretation of opinions and attitudes of students, parents, and, subject teachers.

To provide recommendations towards a greater concentration and awareness of educational actors for greater access in terms of teacher training teachers for a class teacher.

\section{Critical access of the study theory}

The teacher and the student are important fundamental factor in the school, which influence and operate depending on each other as in the educational process as well as outside it. Teacher is given a lot of tasks that must be completed in its educational work, especially in his role as a class teacher, who with his hard work and responsibility that he has, reaches the realization of the objectives set before him. In order to evaluate the performance of the class teacher, we should look not only the administrative side of documentation leadership or in the achievements and attendance of students, but should also look the other very important aspects such as social an organizational of school life. When we say social aspect, we mean creation of a positive climate in the classroom in which the relationships created inside the classroom between students, parents and subject teachers are included, which is essential for a proper upbringing and a quality education. There are different understandings of the role of the class teacher and its specific tasks which should be with the class. According Sijakovicit, (2011:19),

Democratic and cooperative atmosphere contributes to a greater connection and closeness between students. Common activities of teachers, parents and peers, in and outside the classroom, are of a great importance for optimal intellectual development and socio-emotional development of students.

There are also other understandings that determine the role of the class teacher.

The class teacher is the main factor of the dynamic structure of the class. With his relationship to students and connections that developed between him and the students can significantly affect the atmosphere in the classroom and in the academic success. Also, the teacher in the role of the class teacher is more likely than others to contribute to the promotion and development of various social skills of students of his class. Obradovic\&Lukic,2007:20-21).

Relying on these understandings, we notice that the class teacher is the one who with his actions creates an overall positive climate in the classroom. On the other hand in creating a positive warm climate in the classroom, enters also the creation of a trust and respect between students, students and subject teachers, and this can make the class teacher, who with his communication ability as an assistant, close, honest, open and cooperative with all, he creates a mutual trust and respect.

Rukiqi states that, "Showing respect during the conversation means to appreciate all those who take part in the conversation. Cooperation requires confidence in each other. Confidence is achieved through dialogue. To create confidence to each other, time, shared conversations, active dialogue with long goals are required".(Rukiqi,2012;87).

On the other hand we see the family as a relevant factor of children's school life, as an important partner of the class teacher, without whom the goals set out in the education and achievement of a successful work of the class teacher wouldn't be accomplished.

The class teacher is the first link in the long chain of communication between parent and school. From the way he approaches the parents, informs, organizes and leads, will largely depend, not only the attitude of parents towards him personally but also towards the school in general, and not rarely attitudes of parents will be support and a start of students' attitudes". (Sijakovic, 2011: 18).

In order, a quality and efficient cooperation, as well as to build a socio-emotional climate in the school between the class teacher and parents to be achieved, necessary is the systematic communication as a key to creation of a mutual trust and respect between the class teacher and parent.

Hasani, states that "Credibility, respect and mutual communication class teachers and parents are three very important elements when considering the recognition of children and giving parents information for personal development, emotional, skills development and educational achievement of children and creation of the enough space as a good opportunity for 
parents to give their contributions by giving ideas, suggestions and opinions regarding school work and their children school life."(Hasani, 2013:56).

Credibility, respect, cooperation, flexibility, willingness and support offered to students by the class teacher are important parameters by which pedagogical work of the class teacher is conditioned. On the basis of this theoretical approach, we notice that the class teachers' work is too hard with dedication and responsibility, in order to put up the realization of the objectives which he gave to himself with the only purpose of functioning as a whole class and to contribute to a positive working climate and interpersonal.

\section{The study methodology}

Through critical approach of the literature an overview of different theories on the study problematic is presented. This study was approached by using methodological qualitative and quantitative methods, where descriptive methods are applied, which describe the evaluation of the work of the class teacher according to the perceptions and opinions of students, parents and subject teachers, methods of theoretical analysis, through which various theories have been analyzed, the method of comparison and the statistical method where an analysis of the data was made. The instrument used in this study was a questionnaire for students, parents and subject teachers, each questionnaire contained 24 questions that had to do mainly with the work of the class teacher. Participants in the survey were 60 graduated students, 40 parents and 20 subject teachers of a high secondary school in the city of Gjilan.

Interpretation, discussion and analysis of the study findings

In this section the degree of satisfaction of students, parents and subject teachers to the class teachers' work is treated. Tables below present the level of evaluation of the organizational work, educational and social of the class teacher from the perspective of students, parents and subject teachers.

Table 1 Evaluation level of student to the class teachers' work.

\begin{tabular}{|l|l|l|l|l|l|}
\hline $\begin{array}{l}\text { Aspects of organizational function, educational and } \\
\text { social of work of the class teacher }\end{array}$ & 1 & 2 & 3 & 4 & 5 \\
\hline $\begin{array}{l}\text { 1. The class teacher is open to communication and is } \\
\text { always willing to listen to the thoughts, ideas or our } \\
\text { complaints }\end{array}$ & 0 & $5 \%$ & $46.67 \%$ & $20 \%$ & $28.33 \%$ \\
\hline $\begin{array}{l}\text { 2. The class teacher helps and advises us in resolving } \\
\text { any problem or dispute with the subject teachers }\end{array}$ & 0 & $10 \%$ & $51.66 \%$ & $21.67 \%$ & $16.67 \%$ \\
\hline $\begin{array}{l}\text { 3. The class teacher is honest, respects us, motivates } \\
\text { and supports us every time. }\end{array}$ & $1.67 \%$ & $10 \%$ & $45 \%$ & $18.33 \%$ & $25 \%$ \\
\hline $\begin{array}{l}\text { 4. The class teacher is polite and behave equally with all } \\
\text { students }\end{array}$ & $5 \%$ & $11.67 \%$ & $38.33 \%$ & $16.67 \%$ & $8.33 \%$ \\
\hline $\begin{array}{l}\text { 5. The class teacher and continuously monitors the work } \\
\text { and the situation in the classroom }\end{array}$ & $5 \%$ & $11.67 \%$ & $46.67 \%$ & $18.33 \%$ & $18.33 \%$ \\
\hline $\begin{array}{l}\text { 6. The class teacher helps us and cooperate in } \\
\text { overcoming difficulties in learning }\end{array}$ & $3.33 \%$ & $8.33 \%$ & $51.67 \%$ & $21.67 \%$ & $15 \%$ \\
\hline $\begin{array}{l}\text { 7. The class teacher always criticizes us and does not } \\
\text { care at all for us }\end{array}$ & $26.67 \%$ & $23.33 \%$ & $31.67 \%$ & $8.33 \%$ & $10 \%$ \\
\hline $\begin{array}{l}\text { 8.I'm Pleased with the work done by the class teacher } \\
\text { and I have full confidence in him }\end{array}$ & $4.33 \%$ & $6.67 \%$ & $41.67 \%$ & $20 \%$ & $28.33 \%$ \\
\hline
\end{tabular}

From the data of the table 1 on aspect: The class teacher is open to communication and is always willing to listen to the thoughts, ideas or our complaints with 5 evaluated $28.33 \%$ of students, with 4 evaluated $20 \%$ of them, with 3 evaluated $46.67 \%$, with 2 evaluated $5 \%$, while evaluations with 1 were none. Analysis of this data shows that the class teacher is 
somewhat open to communicate and is always willing to listen to the thoughts, ideas or students' complaints, which shows that the satisfactory degree of the students is in the middle level.

On aspect: The class teacher helps and advises us in resolving any problem or dispute with the subject teacher, with level 2 evaluated $10 \%, 51.66 \%$ of students evaluated with 3, 21.67\% of them evaluated with 4 and with 5 evaluated $16.67 \%$ of students, while with the level 1 there was no evaluations. Based on the analysis of these data we can say that a large percentage of students evaluated with an average level, which means that students are not very pleased with the help and advice given to them by the class teacher for problems solving or disputes with subject teachers.

With an average level, students have appreciated the sincerity, respect, motivation and support from the class teacher, where 25 percent of students were evaluated with 5, 23.33 percent evaluated with 4,45 percent with 3 , with 2 evaluated $5 \%$ and 1.67 percent evaluated with 1 . Analyzing these data we see that they have a support, respect and motivation. Respect, the support and students motivation by the class teacher are three very important elements when considering a child's personality and his intellectual development.

From the analysis of the fourth aspect that the class teacher is polite and behaves equally with all students, we can conclude that it is noticed that there is the unequal treatment of students by the class teacher. Analysis of the evaluation level of continuous tracking of the situation in the classroom by the class teacher shows that the highest percentages of students are not satisfied. Another aspect that has to do with the help and cooperation that the class teacher offers students to overcome learning difficulties, evaluated with 41.67 percent of students, with sufficient level 8.33 percent, with nonsufficient level or 1 evaluated 3, 33 percent, with 4 evaluated 21.67 percent and with the level 5 evaluated 25 percent. Analysis of these data shows that the class teacher significantly does not provide enough assistance and cooperation to students to overcome the difficulties in learning.

Another aspect that has to do with criticism and insults by the class teacher is evaluated at a lower rate, what we see that very few students have expressed that there is this negative feature which causes resentment among students and not interest for the school. With the analysis of student satisfaction with the work of the class teacher we see that students are on a par satisfied with the work that their class teacher does, which tells that class teachers are less engaged.

Table 2 .Evaluation level of parent to the class teachers' work.

\begin{tabular}{|l|l|l|l|l|l|}
\hline $\begin{array}{l}\text { Aspects of organizational function, educational and } \\
\text { social of work of the class teacher }\end{array}$ & 1 & 2 & 3 & 4 & 5 \\
\hline $\begin{array}{l}\text { 1. The class teacher consults with us any time for } \\
\text { work and school life of our children }\end{array}$ & $43.33 \%$ & $31.67 \%$ & $13.33 \%$ & $11.67 \%$ & 0 \\
\hline $\begin{array}{l}\text { 2. The class teacher regularly informs us about the } \\
\text { achievements, progress and attendance of our } \\
\text { children }\end{array}$ & $41.67 \%$ & $28.33 \%$ & $15 \%$ & $15 \%$ & 0 \\
\hline $\begin{array}{l}\text { 3. The class teacher every time requires assistance } \\
\text { in case of need, support, and cooperation }\end{array}$ & $16.67 \%$ & $25 \%$ & $38.33 \%$ & $11.67 \%$ & $8.33 \%$ \\
\hline $\begin{array}{l}\text { 4. The class teacher during parents meetings is very } \\
\text { discreet in his speech and never labels students }\end{array}$ & 0 & $5 \%$ & $48.33 \%$ & $26.67 \%$ & $20 \%$ \\
\hline $\begin{array}{l}\text { 5. The class teacher often organizes joint meetings } \\
\text { with parents, subject teachers and students }\end{array}$ & $90 \%$ & $10 \%$ & 0 & 0 & 0 \\
\hline $\begin{array}{l}\text { 6.I'm satisfied with the class teacher because the he } \\
\text { is always ready to meet us and exchanges thoughts } \\
\text { and good ideas for the benefit of our children }\end{array}$ & $11.67 \%$ & $26.67 \%$ & $28.33 \%$ & $8.33 \%$ & $25 \%$ \\
\hline $\begin{array}{l}\text { 7. The class teacher organizes meeting with subject } \\
\text { teachers, if required }\end{array}$ & $15 \%$ & $16.67 \%$ & $28.33 \%$ & $25 \%$ & $15 \%$ \\
\hline
\end{tabular}

In the table 2 the aspect that the class teacher consults with parent any time for work and school life of their children was low evaluated, from this we see that parents are not satisfied with the opportunities to be consulted by the class teacher. 
In the aspect that the class teacher regularly informs parent about the achievements, progress and attendance of their children, parent evaluated low, what is seen that parent are not satisfied with the information from the class teacher. So, there are lacks of parents regularly information about the progress and attendance of students, which is primary because the regular information enables the family receive important information about the development state in general of the child and to parents a sense of trust and respect for the class teacher is created and finds support from family.

The class teacher, any time in case of need, requires help, support, and collaboration. This aspect is low estimated by the parents. Lack of help seeking, support or cooperation can lead to mistrust in class teacher but also in the school as a whole. Shared responsibility is more than necessary to overcome the situation.

The aspect, the class during parent meetings is more discreet in his speech and never labels the students, parents have evaluated good, which shows that they are satisfied with the manner of holding meetings, because labelling a child means to break the personality of the child but also of the parent.

The class teacher often organizes joint meetings with parents, subject teachers and students. This aspect is very low estimated with a high percentage of parents. Common parent meetings, student and subject teachers contribute greatly to children's development and in these meetings the real digest of students development can be appear, what parents will be familiar and specifically with their children's achievements.

I am satisfied with the class teacher because he is always ready to meet with us and exchange thoughts and good ideas for the benefit of our children. The data in the table associated with this aspect shows that a high percentage of parents are not satisfied with the meetings with the class teacher. Frequent meetings with the class teacher make different opinions be respected; the parent would feel himself equal to the exchange of ideas and would be more motivated.

When we ask, the class teacher organizes meeting with subject teachers. Parents are not very satisfied with this aspect of the class teacher. Parents meeting, with the subject teachers is of particular importance because during this meeting the parent recognizes closely the work, progress, delays in learning or his attendance in teaching.

Table 3 .Evaluation level of subject teachers to the class teachers' work.

\begin{tabular}{|c|c|c|c|c|c|}
\hline $\begin{array}{l}\text { Aspects of organizational function, educational and } \\
\text { social of work of the class teacher }\end{array}$ & 1 & 2 & 3 & 4 & 5 \\
\hline $\begin{array}{l}\text { 1. The class teacher organizes meetings with us to see } \\
\text { the progress and the work of his students }\end{array}$ & $90 \%$ & $10 \%$ & 0 & 0 & 0 \\
\hline $\begin{array}{l}\text { 2.I'm Pleased with the class teachers, with the } \\
\text { organizational way and the support and assistance in } \\
\text { resolving any dispute in their class }\end{array}$ & 0 & 0 & $45 \%$ & $30 \%$ & $25 \%$ \\
\hline $\begin{array}{l}\text { 3. The class teachers do not interfere in our educational } \\
\text { work, especially in terms of assessing }\end{array}$ & & $10 \%$ & $25 \%$ & $30 \%$ & $35 \%$ \\
\hline 4. We are always supported by the class teachers & 0 & 0 & $75 \%$ & $15 \%$ & $10 \%$ \\
\hline $\begin{array}{l}\text { 5. During meetings with parents, the class teachers } \\
\text { organize special meeting with the subject teachers. }\end{array}$ & $100 \%$ & 0 & 0 & 0 & 0 \\
\hline $\begin{array}{l}\text { 6. Class teachers interfere in evaluation process and } \\
\text { require higher marks. }\end{array}$ & $90 \%$ & $10 \%$ & 0 & 0 & 0 \\
\hline
\end{tabular}

The class teacher organizes meetings with us, in order to see the progress and work of his students. This first aspect is assessed with 1 by 90 percent of subject teachers, with 2 have estimated 10 percent. With the analysis of these data we see that class teachers do not organize meetings with subject teachers to discuss progress and work of his students. An organization of such meetings would enable better access to students, would better know their students, would better see of the communication between subject teachers and students, subject teachers also would be recognized in detail with the students.

I am pleased with the class teachers, their organizational way and with their help and support in resolving any dispute in their class. With this aspect subject teachers are pleased and have evaluated highly the organizational work, help and 
support of the class teachers in resolving any disagreements that exist between subject teachers and students. So, 45 percent of them have evaluated with 3, with 4 have evaluated 30 percent and with 5 have evaluated 25 percent of parents.

The class teachers do not interfere in our educational work, especially in terms of evaluation. From the analysis of the data obtained of assessing of this aspect results, that subject teachers are satisfied with the class teachers because they do not interfere in their work, especially in evaluation, because evaluation is a very sensitive issue and there are cases where the class teacher requires from the subject teachers a best rating in his class.

During parent meetings class teachers organize a special meeting, subject teachers-parents. From the analysis of the data collected for this aspect we see that all the subject teachers were of the same opinion that class teachers do not special parent-subject teachers, which is very necessary because such an arrangement would enable parents to better informed about the progress, stagnation, child behaviour in that subject, than the information by the class teacher about something that they do not know how was that student in that subject but based only on his note in the diary.

Class teachers interfere in evaluation process and require higher marks. With the data analysis for this aspect, we say that 90 percent of teachers have evaluated low with 1 and 10 percent of them with 2, where we note that we do not have intervention to subject teachers in terms of evaluating.

Opinions of students and parents

The class comes every time my in our class and inquires if we have a problem, if we have got good grades.

The class teachers behaves well with $u$, never within three years has ever offended us, we always have seen him in humour and is equally with all.

Our class teacher is never interested in us; does not behave well enough with us as the other class teachers behave with their students, for us is the same, with or without the class teacher.

The class teacher has never organized any school activity inside or outside the school.

The class teacher of my child's is not very communicative; when we come to any informal meeting he wants to take us away.

The class teacher only in parent meetings calls us and talks more with the parents of some students and misses the rest of us.

The class teacher must inform us every weekend about the performance and attendance of the children in school.

The class teachers should engage more in order that their students to succeed and have a positive view of the school.

\section{Discussion and conclusions}

- The data obtained show that students and subject teachers have evaluated to the average level the work of the class teacher, while parents were superstitious of the class teachers' work judging that the cooperation and communication that is not at the right level. Parents prejudice the class teacher as non-cooperative, non-communicative and not seeing off their children's school work.

- Based on the data obtained it can be concluded that the class teachers in their organizational, educational and social role do not work enough to satisfy the needs and demands of students for a better approach to their school.

Based on the perceptions of these three relevant factors we conclude that the work that needs to lead and direct the class teacher is very difficult, with multiple tasks, with more responsibility and with many difficulties, because in order to form a successful class in all aspects, the class teacher should be professionally prepared in terms of pedagogical, organizational, administrative and in the other hand he must communicate regularly with all stakeholders, to create a mutual respect and trust between the pairs and should be willing and open to dialogue and these elements would help the functioning of a successful cooperation. That in the future to have a successful, quality and effective job of the class teachers, special programs for the class teachers' work, for the young student studying teaching should be compiled, seminars and trainings organization, where teachers for their work on the role of the class teacher will be prepared in the educational, professional, and methodological quality way. Also, specific guidelines that will give explanations, instructions and tips on how to work with the class in all aspects ranging from pedagogical, organizational, administrative, for the ways of cooperation and communication with students, parent and subject teachers should be compiled, in order to achieve quality work and to form 
a successful class. This study will probably be a push towards concentration of attention of higher educational institutions in the work of the class teacher.

\section{References}

Glasser, W.(1993).Nastavnik u kvalitetnoj skoli.[Teacher in quality school] Zagreb:Educa,1999.

Gordon, T.(1998).Kako biti uspesan nastavnik.[How to be a successful teacher] Beograd: Kreativni centar.

Hasani, N. (2013) . Angazhimi i kujdestarit të klasave në nxitje të prindërve për bashkëpunim. Studime sociale[Engaging of the class teacher in incentive of parents for cooperation] [Social studies]3(7),55-62.

Kamenarac,O.(2009).Razvoj komunikacijskih kompetencija-potreba i nuznost.[Development of communication competences- need and obligatory] Beograd: Zaduzbina Andrejevic.

Malic,J.(1973).Razrednik u osnovnoj skoli.[ The class teacher in primary school] Zagreb: Skolska knjiga

Obradovic R.,Lukic,I. (2007)Odeljenski staresina.[The class teacher] Beograd:Kreativni centar

Selakovic,J."Putevi i nacini komunikacije izmedu roditelja i skole“. [Ways and forms of communication, between parents and the school] Internet:http://www.cipcentar.org/i roditelii se pitaju/index.php/biblioteka/87-clanci/102-putevi-i-nacinikomunikacije-izmedu-roditelia-i-skole, ,Prill.9,2012 [visited 11/4/2013.]

Sijakovic,T.(2011).Odeljenski staresina-aktivnosti pod lupom.[ The class teacher- activities] Beograd: Zaduzbina Andrejevic.

Stajls,D.(2005).Odeljenski sastanci.[ Class meetings]Beograd:Kreativni centar.

http://www.scribd.com/doc/160172803/Priru\%C4\%8Dnik-za-odeljenske-stare\%C5\%A1ine

http://uspesannastavnik2012.wordpress.com/category/kako-biti-uspesan-nastavnik/ 4/19/2014

https://sites.google.com/site/pomocnikunastavi/odelenski-staresina/casovi-odelenskog-staresine 